\title{
What's in a Name? Shifting Identities of Traditional Organized Crime in Canada in the Transnational Fight against the Calabrian 'Ndrangheta'
}

\author{
Anna Sergi* \\ University of Essex
}

Les autorités antimafia italiennes ont prévenu la police canadienne des risques et des préoccupations croissantes concernant l'infiltration de clans faisant partie de la mafia calabraise, connue sous le nom de 'ndrangheta dans l'Est canadien'. L'alerte liée à l'essor de la 'ndrangheta défie les paradigmes du crime organisé traditionnel au Canada parce que la 'ndrangheta est présentée comme étant non seulement traditionnelle, mais aussi novatrice et plus omniprésente que d'autres groupes de type mafia. En accédant à des enquêtes confidentielles et en interviewant des spécialistes clés à Toronto et à Montréal, cet article examine la perception institutionnelle actuelle de la mafia particulièrement la 'ndrangheta - au Canada comparée aux conceptualisations italiennes. Je soutiens que les changements de narratifs au Canada peuvent être compris en lien avec des changements concernant l'identité italienne dans le pays, allant vers une régionalisation et une connaissance spécialisée des différences ethniques.

Mots clés : mafia, crime organisé italien, police, mobilité de la mafia, migration italienne, crime organisé

The Italian antimafia authorities have warned Canadian law enforcement about the risks and the growing concerns for the infiltration of clans of the Calabrian mafia, known as 'ndrangheta, in Eastern Canada'. The alarm linked to the rise of the 'ndrangheta challenges the paradigms of traditional organized crime in Canada, because the 'ndrangheta is presented as traditional but also innovative and more pervasive than other mafia-type groups. Through access to confidential investigations and interviews to key specialist law enforcement teams in Toronto and Montreal, this article investigates today's institutional perception of mafia - the 'ndrangheta in particular - in Canada when compared to Italian conceptualizations. I will argue that the

* Please direct correspondence to Anna Sergi, Department of Sociology, University of Essex, Wivenhoe Park, Colchester, Essex, UK, C04 3SQ; asergi@essex.ac.uk 
changes in narratives in Canada can be read in relation to changes in the Italian identity in the country, moving towards regionalization and specialist knowledge of ethnic differences.

Keywords: mafia, Italian organized crime, policing, mafia mobility, Italian migration, organized crime

\section{Introduction and methods}

In the past 10 years, the Calabrian mafia, known by the collective name 'ndrangheta [honoured society] from the southern Italian region of Calabria, has been the object of increasing attention and focus of law enforcement, media, and researchers. According to the Italian National Antimafia Prosecutor, "the criminal infiltration of the "ndrangheta in North America (Canada and United States) is now complete" (DNA 2017: 31) and the "ndrangheta appears "rooted in Canada and in particular in Ontario and in the city of Toronto where different 'locali' ${ }^{4}$ operate" (35).

The increased and still growing focus on this mafia can be linked to several factors. First, Italian antimafia authorities with Operation Crimine $^{5}(2008-2016)$ have demonstrated that the clans of the southern part of Calabria have developed a certain degree of organization, and these organizational skills have successfully rooted outside Calabria in European countries like Germany and Switzerland and, beyond North America, also in Australia (Sergi and Lavorgna 2016). Second, the institutionalized judicial agreement on the existence of unitary coordination structures across 'ndrangheta clans in Calabria has rekindled tales of the existence of a mafia conspiracy across the world; this echoes the times when the Sicilian mafia, Cosa Nostra, was made the object of movies and books and became the most popular form of organized crime worldwide (Lupo 2002). Third, the internationalization of some 'ndrangheta clans and their activities has posed new and various questions on the mobility of crimes and criminals more generally (Varese 2011). These questions reignite the debate on the appropriateness of ethnicity as a tool for the investigation and comprehension of organized crime networks.

This work originates from a broader research project conducted in Australia and Canada; it will present research conducted in Canada, specifically in Toronto and Montreal. Together with the analysis of reports and judicial documents, qualitative interviews (which remain 
anonymous due to participants' requests), both individual (5) and in the form of focus groups (3), have been conducted with high-ranking, hard-to-reach law enforcement officers (from the Royal Canadian Mounted Police [RCMP] and York Regional Police) mostly engaged in the fight against Italian criminal groups in the two cities. Two research questions at the basis of this article are the following:

1. What is today's institutional perception of mafia and, in particular, 'ndrangheta in Canada when compared to Italian perceptions?

2. How do narratives on mafia and 'ndrangheta in Canada relate to the identity of Italian migrant communities in the country?

To answer these questions, it will be necessary to explore what the term 'ndrangheta indicates, in Italy and abroad, with specific reference to both mafia studies and research on the relationship between ethnicity and organized crime. The main idea behind this project is that before an investigation on the actual presence of the Italian mafia in Canada can be undertaken, it remains imperative to understand the perceptions of the phenomenon by those who are supposed to fight it, beyond Italian-centric views. I will eventually argue that differentiating the "ndrangheta from other forms of "traditional" Italian organized crime (a term that will need explaining) in Canada is quite difficult and, ultimately, useless for law enforcement. The way Italian authorities portray the "ndrangheta clans and their behaviours in Italy and abroad is an object of misunderstanding when measured against Canadian concepts of ethnic and traditional organized crime. Nevertheless, the need to conceptualize ethnic and traditional organized crime in relation to regional specifications (Sicilian mafia, Calabrian 'ndrangheta) follows a more widespread regionalization ${ }^{6}$ of the Italian identity in the country.

\section{What's in a name? The 'ndrangheta, the mafia method, and traditional organized crime}

The term "'ndrangheta" - from Greek etymology, "society of honourable men" or "the honoured society" - is today widely accepted to collectively indicate mafia-type groups in Calabria, or of Calabrian origin elsewhere, that employ mafia behaviour (Sergi and Lavorgna 2016). Mafia-type groups engage in various illegal activities through the use of the "mafia method" or mafia behaviour. As described by the Italian Penal Code, article 416-bis, the mafia method manifests through 1) the actual or threatened use of intimidation and violence; 2) the strength 
(and reputation) of the associative bond; and 3) behaviours of omertat ${ }^{7}$ in the community. These three elements are proven through a thorough analysis on the control (both violent and economic) over the territory the groups exercise and on the groups' ability to pursue illegal financial gains (Fiandaca 2010). As the jurisprudence of article 416-bis of the Italian Penal Code has consistently confirmed, the conceptualization of "mafia" is grounded in the social characteristics of the phenomenon, which also involves stable relationships with local politics (Dalla Chiesa 2010: 36). However, the origins of the mafia in Calabria date back to the unification of Italy, if not before (Ciconte 2011), and the name "'ndrangheta" itself already appeared in the first half of the 1900s to indicate organized criminal behaviours in the region (Trumper et al. 2014); the "ndrangheta was only qualified as "mafia" at the judicial level in 2010. ${ }^{8}$ Operation Crimine has mapped the activities and the structures of the clans in the southern part of Calabria and has demonstrated how there are indeed higher structures for cooperation and conflict resolution management in place to secure the success of criminal endeavours. The findings of Operation Crimine have formed the concept of the 'Ndrangheta, with the capital N, as a complex criminal organization. However, as the mafia connotation already suggests (Paoli 2014), the term "'ndrangheta" refers also to a social phenomenon or, as it has been argued, a "set of behaviours" that are "qualifiers of the mafia method generally intended" and refer to the "ability to manipulate social networks and relationships, more or less linked to family dynamics and certainly entrenched in social structures - in this case, Calabrian ones" (Sergi and Lavorgna 2016: 3). Eventually, "'ndrangheta" particularly refers to mafia behaviours, arranged in different organizational units, in the territories and the sociocultural and political contexts of Calabria.

A complication of the terminology emerges, however, with the internationalization of the clans' activities and presence. Scholars have discussed concepts of "transplantation" or "colonization" (Varese 2011; Sergi 2015), which refer to the ability of the clans to root and create cells and networks abroad. When the focus is kept on the criminal activities carried out, in total or in part, in different territories from the ones where the clans originate, scholars and authorities talk about delocalization (DNA 2012; Lavorgna 2015). Obviously, hybrid forms are more the norm than the exception (Sciarrone and Storti 2014). In a very similar manner to the events surrounding the reception, both institutional and public, of the Sicilian mafia in the United States between 1940 and 1980 (Lupo 2008; Woodiwiss 2015), the conceptualization of the 'ndrangheta abroad loses most of the nuances and the specificity of 
its terminology, privileging less analytical notions instead. For example, in Europe, Australia, the United States, and Canada, in international media as well as in policy briefings and documents, 'ndrangheta almost always appears with the capital $\mathrm{N}$ ('Ndrangheta) and is referred to as a formalized criminal syndicate similar to the mafia or, rather, a nebulous idea of "the Mafia" (Sergi 2017a).

In Canada, the influence of policies and discourses from the United States has significantly shaped conceptualizations and institutional responses to organized crime (Beare and Woodiwiss 2014). The connection between New York-based crime families and crime families in Canadian cities has historically populated not only media and literature but also policing approaches (Beare 1996). Of particular interest for the purposes of this article is the consolidated prevalence of the terms "traditional" or "ethnic" organized crime in policing priorities. In Canada, as in the United States, traditional organized crime and a rather vague idea of "the Mafia" have historically overlapped (Sheptycki 2003; Albanese 2004). Also like in the United States, traditional organized crime in Canada essentially refers to Italian criminal groups, with a not-so-subtle reference to the (presumed yet contestable) rigid hierarchy system of a "Mafia model" of organized crime (Desroches 2005). Additionally, in Canada, like in the U.S., traditional organized crime has also been understood as ethnic organized crime, which is a result of the more or less justified juxtaposition of traditional organized crime with Italian organized crime/mafia. As noted in a 2006 Canada/U.S. Organized Crime Threat Assessment, "Canadian law enforcement refers to all ethnic Italian criminal activity as either Traditional Organized Crime or Italian Organized Crime" (DEA, FBI, and RCMP 2006: 9). While ethnicity has been employed to classify various types of organized crime groups (from Chinese, to Russian, to Albanian, to Japanese, etc.), the archetypal link between traditional and ethnic remains anchored to the Italian mafia as a prototypical organized crime group, rooted in the United States' experience and evolution of the concept of "the Mafia" or "La Cosa Nostra" (Sergi 2017a).

When looking at the 'ndrangheta clans in Canada, therefore, it is necessary to understand how these established concepts of Italian mafias as ethnic and traditional organized crime inform the current understanding of mobile/international Calabrian clans. Crucially, this calls for an assessment of the meaning of what Calabrian ethnicity actually adds to an understanding of Italian criminal groups in Canada. 


\section{Shifting Italian identity(ies) and mafia perceptions in Canada}

Canada has historically been a destination country for many Italian migrants. With particular emphasis on migration numbers and routes in the first half of the twentieth century, and especially in the aftermath of World War II, Canada appears as one of the permanent destination countries (Ramirez 2002) among the top 10 countries abroad where Italians have moved and now reside, together with Argentina, Brazil, the U.S., and Australia (Fondazione Migrantes 2016). Jansen (1988, 1997) reports that over a half-million Italians went to Canada after World War II, and most settled in Toronto and Montreal. Furthermore, and with obvious relevance to this paper, $70 \%$ of Italian-Canadians trace their heritage to Southern Italy, which includes the regions of Sicily, Calabria, Basilicata, Campania, and Puglia. Fundamentally, the largest group, nearly $20 \%$, came from the region of Calabria (Jansen 1988).

Scholars have suggested that migration to Canada has been organized around families and personal networks, and provident societies and cooperatives played a crucial role in maintaining Italian identities and cultural heritage in Canadian cities (Perin and Sturino 1992; Audenino and Tirabassi 2008; Troilo 2011). In nearly a hundred years of migration, the contemporary identity of Italians in Canada is necessarily the result of a complex, hybrid, and constant negotiation between assimilation to Canadian culture and distinctiveness of Italian origins.

In Canada, migration chains, especially of southern Italians, have been based on social structures built around close familism, intense personal friendships, and reciprocal kinship obligations (Ramirez 2002; Troilo 2011). Chain migration is "that movement in which prospective migrants learn of opportunities, are provided with transportation and have initial accommodation and employment arranged by means of primary social relationships with previous migrants" (MacDonald and MacDonald 1964: 82). Migration chains are the typical paradigm of mobility in many destination countries for Italians, and they also lead to the reinforcement of crystallized cultural canons (Hall 1990); the country of origin remains nostalgically far, while sociocultural practices in migrant communities get transmitted and perpetuated in a hybrid manner, also because of the influences of the place of arrival (Franzina 1998; Stellin 2006). This is important to notice, as it allows us to focus on the dichotomy between static and dynamic elements of Italian identities. On one side, chain migration has led to static imageries and representations of what authentic italianità [Italianness] should look like (Harney 
1998); on the other side, however, the growth of cities like Toronto and Montreal have influenced the evolution of dynamic Italian communities, which are constantly shifting and negotiating their identities across locations and generations of Canadian-Italians (Giampapa 2001, 2004).

For purposes of identity formation, on the one hand, campanilismo [hometown loyalty] has been indicated as a strong feature of chain migration, which led to the preservation of local, rather than national, cultures and group commitments (MacDonald and MacDonald 1964; Harney 2015). On the other hand, an "Italian 'national' identity emerged as a result of inter-ethnic engagement in new places of settlement and the active construction of national formation by interested leadership" (Harney 2015: 51). The tendency to view Italian communities in Canada as expressions of ethnic groups has, however, been criticized, as it implies homogeneity of Italian migrants, which is simply not the case (Harney 2015).

In considering the shifting nature of Italian identities in Canadian cities, there are two issues to further consider: first, the increasing importance of regional differences within the "Made in Italy" concept - as diverse components of authentic Italianness - and, second, the relationship between Italian culture(s) or identities - as described so far - and narratives of mafia.

Harney $(2002,2006,2015)$ argues that, notwithstanding the adoption of a language of nationhood for what constitutes being "Made in Italy" and the "authentic" Italian culture in Canada, differences based on Italian regional cultures have emerged since regions were formally established in Italy in 1970. Regional governments started encouraging Italians abroad to engage with their (regional) culture of origin in new ways, usually through the promotion of bilateral agreements for trade and commerce. Harney (2002: 9) notices that "each subnational grouping [not only] has a population base large enough to sustain a sense of groupness within a larger Italian-Canadian community" but also that there are "on-going comparisons not just between immigrants from the North of Italy and those from the South but also between regional groupings with, for example, distinctive dialects and culinary traditions."

Regional differences in displaying an Italian identity also matter in the way organized crime is perceived, fundamentally preserving the (problematic) link between mafia and southern Italian regions. As declared by law enforcement agencies in the US and Canada, "the 
principal Italian criminal groupings in Canada are the Sicilian Mafia and the "Ndrangheta, or Calabrian Mafia" (DEA et al. 2006: 9). Prima facie, a regional attribution of mafia-type organized crime to the south of Italy is maintained. However, it has been argued that stereotypical images of the Mafia as an indiscriminate Italian product are more widespread among Canadians (L'Orfano 2009; Croci and Tossutti 2010). This has pushed Italian-Canadians into a collective effort to defeat the stereotype (Harney 1998). This effort, however, has been complicated by enduring prejudices between northern and southern Italians across different Italian(-Canadian) communities: Southern Italians are considered by northern Italians as lacking essential qualities such as "honesty, independence and the willingness to work," thus more prone to be mafiosi (Sniderman et al. 2002: 13). In other words, Italians and Italian descendants do not want to be associated with mafias, and rightfully so; but if it cannot be avoided, southerners seem to bear the stigma more.

In conclusion, a more precise differentiation of Italian identity based on regional diversities has generally enriched the concept of Italianness, even though it has affected Italian communities more than outsiders, especially from cultural and commercial perspectives. When it comes to mafias and organized crime, growing regionalization tends to reinforce the perception of mafias as products of the Italian South, especially Sicilian and Calabrian Italy (Schachter and Engelbourg 1988).

\section{Italian mafia in Toronto and Montreal: From traditional organized crime to the contemporary 'ndrangheta}

Mass migration from the southern Italian regions of Calabria and Sicily has been considered as a facilitating factor of mafia mobility, both in the case of the Sicilian mafia (Dickie 2004) and in the case of Calabrian 'ndrangheta clans heavily based on blood ties (Sciarrone 2014b). According to the authorities of both Italy and Canada today, the Sicilian-ness of Montreal and the Calabrian-ness of Toronto have characterized a historical difference between Italian mafia settlements in Quebec and in Ontario, even though this can be contested, considering how the rise of Sicilian clans in Montreal was the result of a mafia war with the Calabrian Violi clan and the ultimate murder of Rocco Violi in 1980 (Lamothe and Nicaso 2001; Schneider 2009). Visibly simplistic, this differentiation between Sicilian Montreal and Calabrian Toronto is nevertheless perpetuated by both Italian and Canadian 
authorities. The arrest warrant for the Italian Operation Crimine reads as follows:

In Canada, specifically in the cities of Toronto and Montréal, operates a complex mafia-type criminal organisation, made of various cells which group together different families, some Calabrian and some Sicilian. The leader of this organisation used to be Vito Rizzuto, who - thanks to his links to the [New York-based] Bonanno family and the [Sicilian-based] Cuntrera-Caruana family had created in Montréal a well rooted mafia structure, connected to the one in Toronto and to Italy as well. ${ }^{9}$

According to Schneider (2013: 135), not only is there evidence that the group headed by Vito Rizzuto (and his father Nicolò before him) was powerful within the cocaine market in Montreal and Quebec, but there was also an "aura of respect for, and deference to, Vito Rizzuto ... who was viewed as the most powerful offender in Québec (and all of Canada) ... a major force in forging cooperation and peaceful relations among ... cocaine wholesalers and retailers." 10 Vito Rizzuto ("Le Grand"), who died in 2013, can be considered the last of Sicilian-style mafiosi, respected and honourable, in Montreal. One of the family's lawyers noticed the following:

Under Rizzuto ... the people did not seem to have a negative concept of him ... he would walk down the street and people would get up to shake his hands ... hey, this guy kills people! He seemed like a star!... Nobody now is going to get up and shake hands with the Angels [Hell's Angels, outlaw motorcycle gang], even though they have the same customers! (Interview in Montreal, Concordia University, 29 March 2017)

As has been said, the rise of the Rizzuto family in Montreal between the 1980s and the 1990s followed a violent overturn of some Calabrian crime families in the city (Nicaso 2005; Schneider 2009). It seems to be a well-known and accepted fact that under the leadership of the Rizzutos, Calabrian and Sicilian criminals worked together, notwithstanding the Sicilian-ness of the "management." Since Vito Rizzuto's death in 2013, the RCMP has observed not only that Italian criminals are increasingly of different regional origins, but they also lack a leader comparable to Rizzuto. According to an RCMP officer working on Project Clemenza - which between 2014 and 2016 saw the arrest of over 70 people, mostly Italians - since 2013, "the criminal landscape in the area has been affected and has become chaotic": 
The people who were born in Italy or were first generation ItalianCanadian, there are very few left, many have been also assassinated, there is still violence in the rankings today, in part because of the instability of the situation - that was one of the things that Vito Rizzuto brought, stability and capacity to build alliances. The people who would have those ties with Italy and be more traditional in the way of conducting themselves, and the ways of conducting business, there are very few left at all. (Interview, RCMP, Criminal Operations Team, 30 March 2017)

A different story is the one in Toronto. In Operation Crimine, we read about Calabrian Toronto families:

Judicial chronicles confirm that the Siderno Group of Crime was established in the 1950s by Frank Costello and Albert Anastasia, two members of American "Cosa Nostra" who were Calabrian. Even today, the name indicates some of the most powerful criminal families from Siderno (Calabria) who moved to North America (Toronto primarily) and who keep tight relationships with their original families in Calabria. ${ }^{11}$

In 2015, Italian authorities, during Operation Acero ("Maple") Connection, observed some of the mafia families in Canada, primarily in Toronto. Italian authorities alerted Canadian ones of an existing "scenario of internal fight across the historical 'ndrangheta families from Siderno ... for the control of some areas in the province of Ontario." In addition, as they also noticed violence in Montreal, Italian law enforcement warned, "even though we cannot confirm connections across the killings [in the two cities], it is without doubt that all parties employ a mafia-style reasoning." 12

Canadian authorities acknowledge that Toronto and Montreal both have mafia-type criminality of Italian origin - Sicilian and Calabrian but the cities are different in how mafia criminality manifests. Because of the lack of a charismatic person like Rizzuto, there seems to be much less public attention to the clans in Toronto when compared to Montreal. This might have to do with the fact that, as noticed in the York Regional Police, "Sicilians open up to all other Italians, the Calabrian families in Ontario are way more closed on Calabrian roots, by blood of marriage, it is very difficult to infiltrate or to get informants" (Interview, York Regional Police Detective, Toronto, 13 April 2017). This perfectly echoes the known differences between Sicilian and Calabrian 
mafias in Italy, as the 'ndrangheta's extreme reliance on blood ties makes the organization less permeable (Sciarrone 2014a). However, in Toronto, the presence of Calabrian crime families is widely known, as explained by an RCMP officer:

In Ontario we have about 200 groups that fit the legal definition of organized crime groups, and one quarter of those are what we could call traditional organized crime, which to us is Italian organized crime, both Sicilian and Calabrian.... For several years, traditional organized crime, specifically the 'ndrangheta, was a tactical enforcement priority for [the] whole of Canada.... It is still a priority, but the way priorities are established has changed for the rest of the country as we are over-represented in Toronto. (Focus Group Interview, RCMP, Serious Organized Crime and Combined Forces Special Enforcement Unit, Toronto, 6 April 2017)

Similarly, even though they are all Italians, and in theory the potential exists for individuals and groups from both Montreal and Toronto to "join forces," the peculiar history of both cities does not make this likely to happen.

The families in Toronto now, they have always been there, they used to be more low key ... for us here in Montreal, no, we have now more a "street mafia" than a "cultural" mafia if you know what I mean.... We had violent outbursts in so many different ways, we grew up [with] a more Americanized-style of segregated groups rather than an Italian style. I can see them working together, between Montreal and Toronto, for business, sure, but not to establish themselves here for power status. (Interview, RCMP Criminal Operations Team, Montreal, 30 March 2017)

In the narratives on Italian mafias in Montreal and Toronto, the tendency to conceptualize different criminal groups according to regional origins in Italy is confirmed. However, it is also seen that, in practice, mafia criminality manifests as a hybrid matter across regional groups. The historical conceptualization of Italian mafias in these two cities mirrors the conceptualization of Italianness in Canada - shifting between a static, singular, and national identity on one side and dynamic, plural, and regional manifestations of this identity on the other side. 


\section{Contemporary narratives on the 'ndrangheta in Italy and in Canada}

\section{The hybrid nature of the mafia in Canada}

In Italian discourses, Canada is one of the stable strongholds of the Calabrian mafia around the world (Caneppele and Sarno 2013; Calderoni et al. 2016; Sergi and Lavorgna 2016), with locali [territorial/local structures] in Ontario, especially in Toronto and Thunder Bay, as established by Operation Crimine. ${ }^{13}$ Prima facie, Canadian perceptions of Italian organized crime as traditional organized crime, as a stable presence in the country, match the historical narratives on the 'ndrangheta in Canada presented by Italian authorities. However, when it comes to an updated conception of the 'ndrangheta - as the most powerful Italian mafia and as the most pervasive one abroad - perceptions tend to diverge.

In a nutshell, Italian authorities push for a compact identity of the Calabrian 'ndrangheta - almost as a holding company with subsidiaries around the world and growing in power through strategic centrality in Calabria. Instead, in Canada, Calabrian clans are treated as ethnic/ traditional organized crime [i.e., Italian clans]; regional differences are known, but there is no singularization of the threat. This contrasts with the idea of a compact and increasingly powerful 'Ndrangheta (with a capital N).

These divergent narratives have become even more visible since 2015 and Operation Acero Connection. In this operation, which has uncovered a wide range of criminal activities between the Netherlands, Italy, Switzerland, and Canada, we read about Montreal:

The development of criminal activities and the strategic evolution of the Calabrian 'ndrangheta have progressively altered equilibria also in Canada. At the moment, the interests of the traditional Sicilian mafia have been entirely reduced by the booming expansion of the Calabrian clans. ${ }^{14}$

This echoes the findings of Operation Crimine, where investigators found how some members of the 'ndrangheta in Calabria were doubly affiliated with Sicilian clans in Montreal. For example, in the judgement leading to a deportation order by the Immigration and Refugee Board in Canada against an Italian/Calabrian citizen with permanent 
residency in Canada, the board's decision was based on the man's membership in the 'ndrangheta. The judge recalls,

In 2008, Mr Bruzzese was prosecuted in Italy for being associated with a Sicilian criminal organization [in Canada]. He was ultimately acquitted of that charge. However, in 2010 a warrant for Mr Bruzzese's arrest was issued by the Italian authorities alleging that he was wanted in relation to his alleged association with the 'Ndrangheta. ${ }^{15}$

On the basis of the documentation provided by the Italian authorities, the board concluded that "although Mr Bruzzese testified he was not part of the 'Ndrangheta, that he did not know what it means and that he did not know about is existence":

In reality he possesses the requisite mens rea for membership. The evidence shows that he is part of the organizational structure of the 'Ndrangheta and knows of its criminal nature and criminal activities; at the very least, he must be deemed to know or imputed with that knowledge, given his leadership role in the organization, and the overwhelming criminal history of the group. (Focus Group Interview, RCMP, Serious Organized Crime and Combined Forces Special Enforcement Unit, Toronto, 6 April 2017)

The overlapping between Sicilian and Calabrian affiliations, which was not historically unusual but is less usual today in Italy (Ciconte 2011; Dickie 2011), is a recurring trait in the understanding of the mafia phenomenon in Canada. When asked whether there is any visible difference between Calabrian and Sicilian groups in Montreal, an RCMP officer in Montreal declared that, especially in the aftermath of Vito Rizzuto's death, there was

no difference, here ... no, not here, they adapted to here, they had to adapt to North America first, then Canada, then Quebec, so French heritage, and then Montreal, which is different than the rest of Quebec.... There is no Sicilian mafia sector or Calabrian mafia sector, there are Italian sectors of Montreal, southern Italian mainly. Sicilian mobsters here are the same as the Calabrian mobsters; they operate in the same way, there is no difference in their behaviours because of origin; they are all crooks. (Interview, RCMP, Criminal Intelligence Transnational Organized Crime, Montreal, 12 April 2017)

In practice, this means that even though regional differentiations are known and expected across criminal groups of Sicilian and Calabrian 
extractions, these do not manifest in Montreal, where Italian criminal groups are actually hybrids, made up of both Calabrian and Sicilian criminals as well as other Italians, mainly form the South, and also work with other criminal groups in the city.

Although there are some differences between Montreal and Toronto, the RCMP in Toronto confirms an overlap between Calabrian and Sicilian criminal groups:

Our organized crime groups work together, there is the 'ndrangheta, Cosa Nostra, gangs ... there is a hierarchy, there are higher level individuals, but we see collaboration.... For the Italians [authorities], Cosa Nostra does not collaborate with the 'ndrangheta, but for us, yes, they are hybrid, they had to emancipate, they had to change the rules, they cannot keep the same cultural expectations. They had to bring in individuals that are English, maybe others with some Italian background, who might not be able to go higher in the ranks, as that is about bloodline, but they had to open up and to work with each other. (Focus Group Interview, RCMP, Serious Organized Crime and Combined Forces Special Enforcement Unit, Toronto, 6 April 2017)

This quote demonstrates two different things: On one side, again, the perception of the Italian mafia is a hybrid concept where regionalization is expected but not found in practice. On the other side, the reference to bloodline as the essential promotion criterion to higher rankings in the groups reveals an automatic association of Italian organized criminality in Toronto with 'ndrangheta rules - it is the 'ndrangheta, not the Sicilian mafia, that relies solely on blood ties and endogamy for recruitment and promotion (Pignatone and Prestipino 2013). This confirms a split between criminal activities of Italian groups in Toronto, diverse and hybrid across Italian identities, and their higher organizational levels, more uniform - regional - as 'ndrangheta-based, thus Calabrian-only. This split is a known feature of the 'ndrangheta, as clans usually cooperate with others indiscriminately, especially for drug distribution and trafficking, while maintaining a Calabrian-only core of power (Sergi and Lavorgna 2016).

\section{The Canadian 'ndrangheta}

Together with the importance of bloodline, authorities noticed cultural aspects of the Calabrian clans, such as affiliation and ranking. The RCMP in Toronto noticed the following: 
When they talk about the ranks, and they talk about all these things, and for the Italians [authorities], under Italian law, this can be mafia association, but ... are they ranks that require actions, or are they ranks out of respect? This is something we need to decide, because if they are not engaging in criminality but they carry a rank in the 'ndrangheta, for us, what is that? ... It's very difficult to say he's part of the 'ndrangheta - we can't really say that because what is the 'ndrangheta, here? (Focus Group Interview, RCMP, Serious Organized Crime and Combined Forces Special Enforcement Unit, Toronto, 6 April 2017)

This is specifically related to some Italian findings on the existence of a locale in Thunder Bay, Ontario. While Italian authorities are able to establish the existence of this locale based on the presence of people and elections of new rankings - as rankings are manifestations of the 'ndrangheta as corporate entity (Ciconte 2015) - Canadian authorities cannot infer the same when there are no links to specific crimes to be observed. This is a case where the organizational elements of the 'ndrangheta (in terms of preservation of cultural norms and traditional values) can be observed by both countries, but these do not link with, or support, 'ndrangheta criminal activities for Canadian policing standards.

The characterization of the 'ndrangheta in Canada contrasts with the increasing homogeneity we find in Italian sources. In Italy, the Canadian 'ndrangheta appears tightly linked to a specific area of Calabria: the surroundings of the town of Siderno. In the Italian Operation Bacinella 2, between 2015 and 2017, we read that the people who have been arrested are alleged members of

a mafia-type criminal organisation named 'ndrangheta, which operates in the territory of the Reggio Calabria province, on the national territory and abroad, which is made up of hundreds of clans, articulated in three territorial structures and with an overarching body named "Provincia."16 In particular, one of its manifestations is the clan Commisso of Siderno, a mafia-type criminal organisation, which operates in the area of Siderno and outside of Italy specifically in Canada, in the city of Toronto, organised in different groups all connected through a "society."17

In addition to the Calabrian "Provincia," there is, according to the Italian authorities, an articulation of the "Crimine" in Toronto, to whom the Calabrian-Canadian clans ought to appellate when solving 
issues on Canadian territory. If the Canadian committee cannot solve the issue, then the families in Calabria might intervene as a last resort. The hierarchical subjection of the Canadian Crimine to the Calabrian one has been hinted in various occasions in recent antimafia operations, but it is not as pacific as it first seemed. In the Italian Operation Recupero, intercepted communications among members of the clans show a hierarchy of power among the various families in Toronto, but also that this hierarchy is often questioned, as are the relationships between Canada and Calabria. One of the Canadian affiliates, when discussing the opening of a café in Toronto, which relevant families on the territory were not properly "notified" about, noticed the following:

They have to respect us ... they came here and said that they can handle it ... but I answered that they did not really understand anything, I told them that they shouldn't just do this stuff, that they don't know how things work here ... it's not like there [in Calabria].

He also questions the relationship with the clans in Siderno:

Look, this is not fair, we have always been together [with the clans in Siderno] ... so I said, what the hell are you doing ... seriously ... if you want to do it like this, fine, then we all mind our own business, then. ${ }^{18}$

Calabrian clans need to be situated within the extremely varied contexts of organized crime groups in Toronto and Montreal. Canadian authorities confirm the existence of a virtual "table" around which sit the individuals holding the highest rankings of various criminal groups in both cities. In Toronto, specifically, the RCMP confirms that in the Calabrian clans, some individuals are naturally more important than others, and this also reflects on their ability to liaise with other criminal groups and solve conflicts:

'ndrangheta members might cluster more ... but when there was friction within 'ndrangheta cells, we started seeing who it is that kind of has elevated status ... I guess you can call it Board of Control, if you want to call it that. Everybody is equal, but some are more equal than others? That's it. (Focus Group Interview, RCMP, Serious Organized Crime and Combined Forces Special Enforcement Unit, Toronto, 6 April 2017) 


\section{The "ndranghetization of "traditional" organized crime in Canada as identity (re)definition of Italian mafias}

The attempt to integrate a "new" Italian discourse on the "ndrangheta with the consolidated approach to traditional organized crime groups in Canada results in the controversial 'ndranghetization of Calabrian criminals (Sergi and Lavorgna 2016). This is the process by which the label "'ndrangheta" is attached to offenders and criminal groups of Calabrian origin in an attempt to elevate their threat level. However, this process does not seem to add anything to policing work: calling all Calabrian criminals "'ndrangheta" seems to be just a tactical choice, made to align with the findings and requests of Italian authorities, rather than being strategic for Canadian law enforcement's purposes.

One of the policing successes against Calabrian clans in Toronto in the past years has been Operation Ophoenix, which, since 2013, has led to various arrests and an increased understanding of how traditional criminal groups of Calabrian origin work in the city and in Ontario (Sergi 2017b). This operation is the result of the prioritization of the 'ndrangheta as national threat in Canada, which coincided with Italian investigations on Canadian-Calabrian clans. At the RCMP in Toronto, Operation Ophoenix is described as follows:

We determined, based both on what we knew domestically and what we were learning from engagement with international partners, that the 'ndrangheta is a concern and we have seen it growing over the years. It's not that they weren't known to us before, and it's not that we haven't done investigations on them historically, it was just that we added some political capital into conducting these investigations.

\section{...}

When the 'ndrangheta became a national and tactical priority for us, it was very difficult because people were going around saying 'ndrangheta, 'ndrangheta, 'ndrangheta, but that meant nothing to us; we couldn't do more than we were already doing, that is ... we have to see what they are doing and whether that is organized crime in the first place. (Focus Group Interview, RCMP, Serious Organized Crime and Combined Forces Special Enforcement Unit, Toronto, 6 April 2017)

The necessary but unwelcome process of 'ndranghetization has led to the acceptance of the term "ndrangheta" as the new official name for 
traditional organized crime on the basis that affiliates and criminals tend to be of Calabrian descent and orbit in Calabrian communities. This, however, does not seem to have brought any actual differentiation from other Italian/traditional criminal groups already known to the authorities. Historical difference on geographical location (Montreal versus Toronto) and differences in behaviours associated with the regional origins of certain Italian subgroups (Calabrian migrants slightly differ from Sicilians or northerners) existed before the 'ndrangheta was introduced in public discourse and still persist.

It is accepted and recognized that the 'ndrangheta is Calabrian, that it differs from the Sicilian mafia in origins and evolution, and that deeper and more coordinated investigations in Italy and Canada are signs of increasingly specific knowledge on the clans' modus operandi. However, neither the regional identity of the clans (their being Calabrian) nor their name being added to police work practices provide a special understanding of their behaviours when compared to other Italian clans. As previously seen, regionalization and specifications of local Italian identities are fundamental for the (re)definition of today's Italianness. It makes sense that they would also be increasingly present in policing narratives, even in contradiction with the observed hybridization of Italian criminal groups.

For example, the following was noticed by the RCMP in Montreal:

In Montreal these people [Sicilian criminals] are fully assimilated; Toronto is different because the Calabrese ${ }^{19}$ [criminals] are a bit different. Mothers teach kids dialect.... I would be surprised if anyone here even spoke Italian. Toronto is different, the Italians have assimilated, but, let's say, the 'ndrangheta hasn't, because the Calabrians keep the traditions, the Sicilians are losing theirs.... In Montreal, they [Italian criminals] work with everybody ... you have everybody except the northerners. But this is because in Montreal there are very few northerners anyway that stayed ... it's a southerners', Italian southerners', city. (Interview, RCMP, Criminal Intelligence Transnational Organized Crime, Montreal, 12 April 2017)

Even though these claims are only partially accurate, as most of the initial migration waves from Italy to Montreal were indeed from the northern regions of Italy (Ramirez 2002), these perceptions are still revealing of a tendency to consider the regionalization of Italian identity as increasingly relevant for the understanding of mafia-type criminality. 


\section{Conclusion}

When investigating the institutional perception of the Italian mafia and, in particular, of the 'ndrangheta in Canada, it has been found that the increased alarm linked to the presence of the Calabrian 'ndrangheta clans around the world - in the discourse of Italian authorities - has only superficially affected the way Canadians approach the phenomenon of Italian organized crime. The findings point to an existing tension between the current conception of the "ndrangheta within the conception of traditional organized crime in Canada. As seen, "traditional organized crime," in Canadian law enforcement's perceptions, refers to Italian criminal groups (not specifically Sicilian or Calabrian). As "tradition" refers to stability or permanency of the groups, as well as their features (family, honour, etc.), traditional organized crime groups are therefore those that are stable and permanent. Reference is made here to a vague idea of "the Mafia" overlapping with U.S.-based concepts of American-Sicilian Cosa Nostra.

However, the internationalization and novelty of the 'ndrangheta discourse explodes the limits of these static perceptions and pushes towards more specific ones. Indeed, the transnationality of 'ndrangheta clans has questioned and shifted the identity of what, if anything, constitutes Italian organized crime these days, both in Italy and abroad. The push towards a specialized regionalization of Italian organized crime in Canada mirrors the tendency towards regionalization of the Italian identity across Canadian-Italian communities. In theory, as the differentiation between Sicilian and Calabrian mafias is known to authorities, and Canadian authorities have been alerted by the Italian antimafia about the risks posed by the Calabrian 'ndrangheta in Eastern Canada, it should follow that Italian organized crime in Canada has changed to the point of not being stable and permanent any longer, thus not traditional. The process is, however, not without contradictions and setbacks.

Italian/traditional organized crime in Canada has historically been understood to rely on the ethnicity of migrant groups. The historical evolution of a national Italian identity in Canada corresponds to the historical evolution of traditional organized crime as being the "Italian" mafia. The additional focus on regional differentiation in the past years coincides with the push towards the recognition of the specific characteristics of the 'ndrangheta (as opposed to the Sicilian mafia). As hinted by the RCMP in Toronto, the necessity to cooperate with Italian authorities, as well as a renewed interest in mafia-type crimes in Toronto, has led to a prioritization of traditional organized crime, because there has 
been a political will to do so. The result has been a growing interest and updated knowledge on the presence of the Calabrian 'ndrangheta in Canada, which arguably has been facilitated by the increased regionalization of Italian identity and a subsequent focus on the diversity of regional groups across Italian communities. In other words, dynamic and changing concepts of the mafia and 'ndrangheta in Canada mirror changes in the way the identity of Italian communities in the country has evolved from an inclusive concept of Italianness - the Italian national identity - to a specialist and diverse regionalization of the "Made in Italy" concept.

However, notwithstanding the regionalization and specification of both Italian identities and criminal phenomena linked to the Italian community in the country, there appears to be a mismatch in the way mafia groups seem to capitalize on regional ethnic groups across Montreal and Toronto. This contradicts the effort towards specialist regional knowledge of criminal groups. How exactly Calabrian the Calabrian mafia in Canada is - independently from what Italian authorities say - still needs to be fully investigated, as Canadian law enforcement agencies admit to seeing very hybrid Italian criminal groups. In these networks, being Sicilian or Calabrian or Italian generally does not matter when it comes to criminal activities, but it becomes relevant when looking at the cultural aspects of mafia-type organizations. The lack of an automatic link between the manifested criminal activities and the overarching cultural elements of the 'ndrangheta is the essential difference between Canadian and Italian authorities and one of the reasons for misconception. This is due to different policing strategies in investigating and prosecuting organized crime - whose analysis goes beyond the scope of this article - and, as often is the case between states in different continents, with different legal traditions and languages (Hufnagel 2013), it might create frictions in policing cooperation across the two countries.

However dense, this article leaves more questions than it answers. The most important aspect that will need to be explored is the impact of these complex aspects of ethnicity on the policing of organized crime transnationally. It has already been argued (Sergi 2017a) that cultural awareness needs to be considered in the policing of contemporary forms of organized crime when the mobility of groups is involved. Further research might look at regionalisms in Italian identities abroad and at the way migrant communities approach, preserve, or reject regional cultural canons, including mafia behaviours. In the case of the 'ndrangheta, because of its being Calabrian, policing through cultural 
awareness might disentangle ethnicity of organized crime from a very fuzzy concept of nationality or citizenship and proceed towards more promising venues of understanding how crimes work in society.

\section{Notes}

1 The author is grateful to the International Centre for Comparative Criminology at the Université de Montréal - and, in particular, Professor Carlo Morselli - for the support, in the form of a visiting fellowship, during March and April 2017 while conducting fieldwork for this project. The author is also grateful to Dr Petr Kupka, University of West Bohemia, for his comments on an earlier draft of this article. This article is part of the research carried out thanks to a British Academy/Leverhulme Trust Small Grant, Reference No. SG162187 (2017).

2 L'Est canadien, ici, fait référence aux provinces du Québec et de l'Ontario, aussi connu à l'époque sous le nom du Centre du Canada.

3 Eastern Canada in this case will refer to the provinces of Quebec and Ontario, at the time also referred to as Central Canada.

4 A "locale" (plural locali) is a grouping of four to six clans supporting each other and operational in the same geographical area.

5 Operazione Crimine, Proc. Pen. No. 1389/2008 - Procura della Repubblica Presso il Tribunale di Reggio Calabria Direzione Distrettuale Antimafia Decreto di Fermo di indiziato di delitto.

6 As Italy is divided into 20 different regions with, at times, very specific cultural and socio-economic differences, "regionalization" in the Italian context refers to regional identities.

7 "Omertä" indicates the voluntary silence of those within communities who choose to "mind their own business," either for fear of retaliation or consensus towards criminal groups and their behaviours.

8 The word "'ndrangheta" was added to the offence of mafia membership in article 416-bis of the Italian Criminal Code (law decree converted with changes from Law No. 50, 31 March 2010, in Gazzetta Ufficiale 03.04.2010, No.78).

9 Operazione Crimine, Proc. Pen. No. 1389/2008 - Procura della Repubblica Presso il Tribunale di Reggio Calabria Direzione Distrettuale Antimafia Decreto di Fermo di indiziato di delitto, p.1923. 
10 Project Colisée (2002-2007), Aperçu de la Preuve, Sentence, Cour du Québec, District de Montréal, C.Q. 500-73-002671-069.

11 Operazione Crimine, Proc. Pen. No. 1389/2008 - Procura della Repubblica Presso il Tribunale di Reggio Calabria Direzione Distrettuale Antimafia Decreto di Fermo di indiziato di delitto, p. 776.

12 Operazione Acero Connection, Procura della Repubblica Presso il Tribunale Ordinario di Reggio Calabria Direzione Distrettuale Antimafia, Proc. Pen. No. 7498/2010 R.G. Decreto di Fermo del Pubblico Ministero, p. 132.

13 Operation Crimine, RGNR. DDA 1358/2008 Procura della Repubblica di Reggio Calabria; Sentenza Anno 12 no.106 Tribunale di Reggio Calabria, Sezione GIP-GUP.

14 Operazione Acero Connection, Procura della Repubblica Presso il Tribunale Ordinario di Reggio Calabria Direzione Distrettuale Antimafia, Proc. Pen. N. 7498/2010 R.G. Decreto di Fermo del Pubblico Ministero, p. 67.

15 Carmelo Bruzzese (Applicant) and Minister of Public Safety \& Emergency Preparedness, and Minister of Citizenship \& Immigration (Respondents), the Honourable Mr Justice Barnes, Ottawa, Ontario, 6 October 2016, 2016 FC 1119, p. 2.

16 The "Provincia" is also referred to as the "Crimine."

17 Operazione Bacinella 2, Tribunale di Reggio Calabria - Ufficio del Giudice per le indagini preliminary - Ordinanza di Applicazione di misure cautelari e contestuale Decreto di Sequestro Preventivo - Proc. Pen. No.9202/2009 RGNR DDA, No. 5245/2010 RG GIP, No. 3/2015 R. OCC, p. 3.

18 Operazione Recupero, Tribunale di Reggio Calabria, Proc Pen. No. 1988/ 2008 - R.G.N.R. D.D.A. + No. 1690/2009 - R.G. G.I.P. D.D.A. Ufficio del Giudice per le indagini preliminari, pp. 128-9.

19 The correct wording in Italian would be "Calabresi" (plural), but Calabrese is the way the regional origin is indicated in Canada, both in the singular and in the plural.

\section{References}

Albanese, Jay

2004 North American organised crime. Global Crime 6 (1): 8-18. https:// doi.org/10.1080/1744057042000297945. 
Audenino, Patrizia and Maddalena Tirabassi

2008 Migrazioni italiane. Storia e storie dell' Ancien régime a oggi. Milano: Mondadori.

Beare, Margaret E.

1996 Criminal Conspiracies: Organized Crime in Canada. Scarborough, ON: Nelson Canada.

Beare, Margaret E. and Michael Woodiwiss

2014 U.S. organized crime control policies exported abroad. In The Oxford Handbook of Organized Crime, ed. Letizia Paoli, 545-71. Oxford: Oxford University Press.

Calderoni, Francesco, Giulia Berlusconi, Lorella Garofalo, Luca Giommoni, and Federica Sarno

2016 The Italian mafias in the world: A systematic assessment of the mobility of criminal groups. European Journal of Criminology 13 (4): 413-33. https:// doi.org/10.1177/1477370815623570.

Caneppele, Stefano and Federica Sarno

2013 La presenza internazionale della'Ndrangheta secondo le recenti indagini. Sicurezza e scienze sociali 3: 161-76.

Ciconte, Enzo

2011 'Ndrangheta. Soveria Mannelli: Rubbettino.

Ciconte, E.

2015 Riti criminali. I codici di affiliazione alla 'ndrangheta. Soveria Mannelli: Rubbettino.

Croci, Osvaldo and Livianna Tossutti

2010 A nice place to visit: Italy as seen by Canadians. Modern Italy 15 (3): 277-91. https:/ / doi.org/10.1080/13532944.2010.490337.

Dalla Chiesa, Nando

2010 La convergenza. Mafia e politica nella Seconda Repubblica. Milano: Melampo.

Desroches, Frederick J.

2005 The Crime that Pays: Drug Trafficking and Organized Crime in Canada. Toronto: Canadian Scholars' Press.

Dickie, John

2004 Cosa Nostra: A History of the Sicilian Mafia. London: Hodder \& Stoughton. 
Dickie, John

2011 Blood Brotherhoods: The Rise of the Italian Mafias. London: Sceptre.

DNA

2012 Relazione annuale sulle attività svolte dal Procuratore nazionale e dalla Direzione nazionale antimafia e antiterrorismo nonché sulle dinamiche e strategie della criminalità organizzata di tipo mafioso nel periodo $1^{\circ}$ luglio 2011-30 giugno 2012. Roma: Direzione Nazionale Antimafia.

DNA

2017 Relazione annuale sulle attività svolte dal Procuratore nazionale e dalla Direzione nazionale antimafia e antiterrorismo nonché sulle dinamiche e strategie della criminalità organizzata di tipo mafioso nel periodo $1^{\circ}$ luglio 2015-30 giugno 2016 (Vol. Prot. 12720/2017/PNA). Roma: Direzione Nazionale Antimafia e Antiterrorismo.

The Drug Enforcement Administration (DEA), the Federal Bureau of Investigation (FBI), and the Royal Canadian Mounted Police (RCMP)

2006 Canada/US Organized Crime Threat Assessment. Washington, DC: DEA, FBI, and RCMP.

Fiandaca, Giovanni

2010 Il concorso "esterno" tra sociologia e diritto penale. In Scenari di mafia. Orizzonte criminologico e innovazioni normative, ed. G. Fiandaca and C. Visconti, 175-82. Bologna: Giappichelli.

Fondazione Migrantes

2016 Rapporto Italiani nel Mondo. Todi: Tav Editrice.

Franzina, Emilio

1998 La storia altrove: Casi nazionali e casi regionali nelle moderne migrazioni di massa. Verona: Cierre.

Giampapa, Frances

2001 Hyphenated identities: Italian-Canadian youth and the negotiation of ethnic identities in Toronto. International Journal of Bilingualism 5 (3): 279-315. https://doi.org/10.1177/13670069010050030301.

Giampapa, Frances

2004 The politics of identity, representation, and the discourses of selfidentification: Negotiating the periphery and the center. In Negotiation of Identities in Multilingual Contexts, ed. A. Pavlenko and A. Blackledge, 192-218. Toronto: Multilingual Matters. 
Hall, Stuart

1990 Cultural identity and diaspora. In Identity, Community, Culture and Difference, ed. J. Rutherford, 222-37. London: Lawrence and Wishart.

Harney, Nicholas

1998 Eh Paesan! Being Italian in Toronto. Toronto: University of Toronto Press. https:/ / doi.org/10.3138/9781442674318.

Harney, Nicholas

2002 Building Italian regional identity in Toronto: Using space to make culture material. Anthropologica 44 (1): 43-54. https:/ / doi.org/ $10.2307 / 25606059$.

Harney, Nicholas

2006 The politics of urban space: Modes of place-making by Italians in Toronto's neighbourhoods. Modern Italy 11 (1): 25-42. https:/ / doi.org/10.1080/13532940500489544.

Harney, Nicholas

2015 Italian mobilities and circulating diasporas in neoliberal times. In Italian Mobilities, ed. R. Ben-Ghiat and S.M. Hom, 46-91. London: Routledge.

Hufnagel, Saskia

2013 Policing Cooperation across Borders: Comparative Perspectives on Law Enforcement within the EU and Australia. London: Ashgate.

Jansen, Clifford

1988 Italians in a Multicultural Canada. Queenston, NY: Edwin Mellen.

Jansen, Clifford

1997 Italians in Canada in the 1990s. Altreitalie 15: 21-7.

Lamothe, Lee and Antonio Nicaso

2001 Bloodlines: The Rise and the Fall of the Mafia's Royal Family. Toronto: HarperCollins.

Lavorgna, Anita

2015 La 'ndrangheta migrante si espande a Nord Est. Giornale di Storia Contemporanea 18 (1): 45-63.

L'Orfano, Francesca

2009 The overwhelming albatross: Stereotypical representations and Italian-Canadian political and cultural life. Altreitalie 1: 137-57. 
Lupo, Salvatore

2002 Cose Nostre: Mafia siciliana e mafia americana. In Storia di Emigrazione Italiana, ed. Piero Bevilacqua, Andreina De Clementi, and Emilio Franzina. Milano: Donzelli Editore.

Lupo, Salvatore

2008 Quando la mafia trovò l'America. Torino: Einaudi.

MacDonald, John S. and Leatrice D. MacDonald

1964 Chain migration ethnic neighborhood formation and social networks. Milbank Memorial Fund Quarterly 42 (1): 82-97. https:/ / doi.org/ $10.2307 / 3348581$.

Nicaso, Antonio

2005 Rocco Perri: The Story of Canada's Most Notorious Bootlegger. Canada: John Wiley \& Sons.

Perin, Roberto and Frank Sturino

1992 Arrangiarsi: The Italian Immigration Experience in Canada. Montreal: Guernica.

Paoli, Letizia

2014 The Italian mafia. In The Oxford Handbook of Organized Crime, ed. Letizia Paoli, 121-41. New York: Oxford University Press. https:/ / doi.org/10.1093/oxfordhb/9780199730445.013.025.

Pignatone, Giovanni and Michele Prestipino

2013 Cosa Nostra e 'ndrangheta: due modelli criminali. In Atlante delle Mafie. Storia, economia, società, cultura. Volume Secondo, ed. Enzo Ciconte, F. Forgione, and Isaia Sales. Soveria Mannelli: Rubbetiino.

Ramirez, Bruno

2002 In Canada. Roma: Donzelli Editore.

Schachter, Gustav and Saul Engelbourg

1988 The steadfastness of economic dualism in Italy. Journal of Developing Areas 22 (4): 515-26.

Schneider, Stephen

2009 Iced: The Story of Organized Crime in Canada. Mississauga, ON: Wiley and Sons.

Schneider, Stephen

2013 Violence, organized crime, and illicit drug markets: A Canadian case study. Sociologia, Problemas e Praticas 71: 125-43. 
Sciarrone, Rocco

2014a 'Ndrangheta: A reticular organization. In The 'Ndrangheta and the Sacra Corona Unita: The History, Organization, and Operations of Two Unknown Mafia Groups, ed. Nicoletta Serenata, 81-100. New York: Springer. https://doi.org/10.1007/978-3-319-04930-4_6.

Sciarrone, Rocco

2014b Tra sud e nord. Le mafie nelle aree non tradizionali. In Mafie al Nord. Strategie criminali e contesti locali, ed. Rocco Sciarrone, 5-38. Rome: Donzelli Editore.

Sciarrone, Rocco and Luca Storti

2014 The territorial expansion of mafia-type organized crime: The case of the Italian mafia in Germany. Crime, Law, and Social Change 61 (1): 37-60. https://doi.org/10.1007/s10611-013-9473-7.

Sergi, Anna

2015 The evolution of the Australian 'ndrangheta: An historical perspective. Australian and New Zealand Journal of Criminology 48 (2): 15574. https://doi.org/10.1177/0004865814554305.

Sergi, Anna

2017a From Mafia to Organised Crime: A Comparative Analysis of Policing Models. London: Palgrave Macmillan. https://doi.org/10.1007/9783-319-53568-5.

Sergi, Anna

2017b Tale of two cities: Criminal groups compete in Eastern Canada. Jane's Intelligence Review (July): 40-3.

Sergi, Anna and Anita Lavorgna

2016 'Ndrangheta: The Glocal Dimensions of the Most Powerful Italian Mafia. London: Palgrave Macmillan.

Sheptycki, James

2003 The governance of organised crime in Canada. Canadian Journal of Sociology 28 (4): 489-516. https://doi.org/10.2307/3341839.

Sniderman, Paul M., Pierangelo Peri, Rui J.P. De Figueiredo Jr., and Thomas Piazza

2002 The Outsider: Prejudice and Politics in Italy. Princeton, NJ: Princeton University Press. 
Stellin, Monica

2006 Bridging the Ocean: Italian Literature of Migration to Canada. Udine: Forum.

Troilo, Matteo

2011 Lavoro ed imprenditoria degli italiani inCanada, tra vecchie e nuove generazioni. Diacronie: Studi di Storia Contemporanea 5: 1-19.

Trumper, John B., Marta Maddalon, Antonio Nicaso, and Nicola Gratteri

2014 Male Lingue. Vecchi e Nuovi Codici delle Mafie. Cosenza: Pellegrini.

Varese, Federico

2011 Mafias on the Move: How Organized Crime Conquers New Territories. Princeton, NJ: Princeton University Press. https://doi.org/10.1515/ 9781400836727.

Woodiwiss, Michael

2015 The analysis and containment of organized crime in New York City and beyond: An interview with James B. Jacobs. Trends in Organized Crime 18 (1-2): 86-93. https:/ / doi.org/10.1007/s12117-014-9231-y. 